\title{
Sóvirág (Limonium gmelini) prolintermelésének összefüggése a sótartalommal természetes és kontrollált környezetben
}

\author{
MURAKEÖZY ÉVA PATRICIA, NAGY ZOLTÁN és TUBA ZOLTÁN \\ Szent István Egyetem, Növénytani és Növényélettani Tanszék, Gödöllő
}

A szántóföldi növénytermesztés legjelentősebb terméscsökkentő tényezői a különböző abiotikus stresszek, melyek között vezető helyen áll a szárazságstressz és a sóstressz (BOYER, 1982). Magas sótartalmú talajok jellemzik a kontinensek összterületének 10 \%-át (SZABOLCS, 1994), mely talajok a múvelésből eleve kiszorulnak. Ezen felül az intenzív növénytermesztés maga is okozója lehet sófelhalmozódásnak, a nem megfelelő öntözési technikák révén. Ez az ún. másodlagos sófelhalmozódás a müvelt területek mintegy 40 \%-át sújtja (WYN JONES \& GORHAM, 1986). Hazánk területének egytizedét teszik ki a szikes talajok (SZABOLCS, 1981).

Noha a mezőgazdasági termesztésben lévő fajok nem, vagy csak igen kismértékben toleránsak a magas sótartalmú környezettel szemben, bizonyos növényfajok (az ún. halofiták) alkalmazkodtak a sós környezethez. A kétszikü halofita és halotoleráns növények sós környezetben az ozmotikus szabályozást elsősorban ionfelvétel és hajtásba való transzlokáció révén valósítják meg (FLOWERS et al., 1977). Mivel e növények enzimrendszere éppoly érzékeny a magas sókoncentrációra, mint a nem halofitáké (FLOWERS, 1972; GREENWAY \& OSMOND, 1972), a megfelelő belső ozmotikus nyomás fenntartásához szükséges sókat a vakuolumba zárja a növény, míg a citoplazma és a vakuolum közötti vízpotenciál-különbséget szerves molekulák akkumulációja révén egyenlíti ki. Ily módon enzimtoxicitás veszélye nélkül, kis energia befektetéssel nő a belső ozmotikus nyomás. A citoplazmában felhalmozódott szerves molekulák az enzimmüködésre még nagy koncentrációban sem károsak (kompatibilis ozmotikumok), segítenek a membránok, fehérjék natív szerkezetének fenntartásában (LOW, 1985), sőt, felhalmozásuk bizonyos metabolikus előnyökkel is járhat (HARE et al., 1998).

A kompatibilis ozmotikumok között tartjuk számon a prolin aminosavat (YANCEY et al., 1982), melynek specifikus akkumulációja általános jelenség a vízhiánynak kitett sejtekben, baktériumokban, algákban és fejlettebb növények-

*A Magyar Talajtani Társaság és a Magyarhoni Földtani Társulat Mérnökgeológiai Szakosztálya 2000. február 9-én, a szikesedés témakörében rendezett előadóülésén elhangzott előadás anyaga 
ben éppúgy, mint állatokban (STEWART, 1981). A magasabb rendủ növényekben felhalmozása jellemző kíséröje a vízhiány-, só- és hidegstressznek. Számos vizsgálatban erős korrelációt találtak a megnövekedett sejtbéli prolintartalom és a sejt szárazság-, illetve sóstressztürő képessége között (TAYLOR, 1996). A prolintartalom biológiai markerként szerepelhet a gyakorlati fajtanemesítési kutatásokban; így a hidegtoleranciára való nemesítésben öszi búzában (DÖRFLING, 1993) vagy sótoleranciára való nemesítésben burgonyában (MARTINEZ et al., 1996). Más esetekben viszont a prolintermelés inkább tekinthető stressz-szimptómának (LUTTS et al., 1996, LARHER et al., 1993; IBARRA-CABALLERO, 1987). Az említetteken kívül a prolinnak valószínűleg fontos szerepe van a nitrogénraktározásban és nitrogénellátásban a gátolt növekedési folyamatok esetén (stresszhatás alatt), valamint könnyen metabolizálható szén- és nitrogénforrást jelent a stresszhatás megszüntekor (GREENWAY \& MUNNS, 1980). Bizonyított, hogy a prolin lebontása a mitokondriumokban közvetlen kapcsolatban áll a légzési elektron transzportlánccal és az ATP-termeléssel (ELTHON \& STEWART, 1981), tehát a prolin lebontása közvetlenül javítja a sejt energiaállapotát.

Noha a prolinválasz majdnem 50 éve a növényi stresszélettani kutatások homlokterében áll, pontos szerepe a magasabb rendủ növényekben mindmáig tisztázatlan és a kutatási eredmények nemegyszer ellentmondásosak. Jelen munka a prolin felhalmozásának és a talaj sótartalmának kapcsolatát vizsgálja a hazai szikesek egyik legszebb halofita növényében, a sóvirágban (Limonium gmelini subsp. hungarica), természetes és kontrollált környezetben.

\section{Anyag és módszer}

Mintavétel természetes növénytársulásból - A mintavételi terület a Kiskunsági Nemzeti Park területén, Fülöpszállás községtöl 4 km-re keletre, a Bordatanya közelében található. A Limonium gmelini subsp. hungarica növényfaj egyedeit Limonio-Artemisietum santonici társulásból választottuk. Mintavétel két időpontban (1999. március és 1999. július, 12 és 13 óra között) történt, egy kb. $5 \mathrm{~m}^{2}$ nagyságú, növényzete alapján homogén területről, 10-10 véletlenszerüen kiválasztott egyed leveleinek begyüjtésével. A leveleket a levélrozetta közepéról választottuk (8-10 cm levélhossz) és a helyszínen folyékony nitrogénben azonnal fagyasztottuk. Talajmintát a kiválasztott növények közeléből, a növények fö felszívási zónájának megfelelően, a felszíntől számított $15-20 \mathrm{~cm}$-es rétegböl vettünk. A mintavétel 3-3 pontból történt, az egyes mintákat összevontan vizsgáltuk. A talajmintát múanyag tasakban tároltuk mérésig.

Növénynevelés kontrollált körülmények között - A leírt mintavételi területen gyüjtött Limonium gmelini subsp. hungarica magokat Petri csészében, desztillált vízzel átitatott papíron, szobahőmérsékleten csíráztattuk. 10 nap elteltével a 
csíranövényeket műanyag tenyészedényekbe $(40 \times 40 \times 20 \mathrm{~cm})$ ültettük, apró szemü kavicsból és perlitből álló közegbe. A perforált aljú tenyészedényeket külön-külön egy-egy tápoldatot tartalmazó másik edénybe helyeztük. Minden kezelésböl két tenyészedény volt, egyenként 12 növénnyel. A Hoagland tápoldathoz (HOAGLAND \& ARNOLD, 1950) a sókezelések esetében négyféle koncentrációban $\left(20,40,60\right.$ és 100 mmól.dm $\left.{ }^{-3}\right) \mathrm{NaCl}$-ot adtunk. A növényeket fitotronban neveltük (Conviron E-15), a nappali/éjszakai $(16 \mathrm{~h} / 8 \mathrm{~h})$ hőmérséklet $24{ }^{\circ} \mathrm{C} / 15{ }^{\circ} \mathrm{C}$ (a hőmérséklet-változás rátája $2{ }^{\circ} \mathrm{C} /$ óra), a megvilágítás erőssége kb. $300 \mu \mathrm{mol} \mathrm{m}^{-2} \mathrm{~s}^{-1}$ fotoszintetikusan aktív sugárzás (PhAR) volt, melyet fluoreszcens lámpák biztosítottak. A tápoldatot hetente egyszer cseréltük. A sófelhalmozódás elkerülése végett 4-hetente a tenyészedényeket felülről desztillált vízzel átmostuk. A 15 hetes korú növényekröl a prolintartalom meghatározásához kezelésenként 5-5 db levelet leválasztottunk, a szabadföldi mintavételhez hasonló eljárással. A mintavételre 13 órakor került sor.

A vizállapot jellemzése növényben és talajban - A nedvességtartalom meghatározása a friss tömeg (FT) és a szárítás után mért tömeg (SZT) alapján történt: (FT-SZT)/FT*100. A relatív víztartalom meghatározása: (FT-SZT)/(TTTSZT)*100, ahol TTT a teljes turgorban mért tömeg. A növényi minták szárítása liofilizálással (24 óra időtartam), a talajminták szárítása szárítószekrényben, tömegállandóságig (kb. 36 óra) történő szárítással történt. A tömegmérésekhez analitikai gyorsmérleget (BOSCH SAE200) alkalmaztunk.

Talaj EC, pH és pNa meghatározása - A talaj vezetőképességét $\left(\mathrm{dS} . \mathrm{cm}^{-1}\right)$, valamint az oxóniumionok $(\mathrm{pH})$ és a nátriumionok $(\mathrm{pNa})$ aktivitását 1:2,5 térfogatarányú talajszuszpenzióban határoztuk meg TóTH (1994) szerint. A telített talajoldat közelítő koncentrációja az 1:2,5 térfogatarányú talajszuszpenzió ECértékéből, Ilaco, valamint Buzás et al. (cit. in TÓTH (1994)) alapján került kiszámításra.

Vizpotenciál meghatározása - A növények vízpotenciáljának meghatározása Scholander nyomáskamrában történt, egész levelek felhasználásával. A talaj vízpotenciálját nyomás-víztartalom görbe alapján határoztuk meg, Wescor HR33T termoelemes mikrovoltméter és a hozzá csatlakozó Wescor C-52 mintakamra segítségével. A mikrovoltmétert harmatpont üzemmódban használtuk.

Ozmotikus potenciál meghatározása levélben - Az ozmotikus potenciál meghatározása páranyomás ozmométer (Wescor 5500) segítségével, $0,8 \mathrm{~cm}$ átméröjü, teljes turgorban lévő levélkorongokon történt, 3 ismétlésben. A teljes turgor eléréséhez a levélkorongokat 8 órán keresztül, $4{ }^{\circ} \mathrm{C}$-on, sötétben, desztillált vízen tartottuk. (A teljes turgor eléréséhez szükséges időtartamot független mérésben állapítottuk meg.) Mérés előtt a levélkorongok felületéröl a vizet itatóspapírral leitattuk. A mintatartó küvettába helyezett levélkorongot folyékony 
nitrogénben tartottuk 1 percig, ezt követően szobahőmérsékleten 5 percig, majd megismételtük a folyamatot. A prolin ozmotikus nyomásának kiszámítása koncentráció-ozmotikus nyomás görbe (LEPORT, 1992) felhasználásával történt. A tápoldatok ozmotikus potenciálját az oldatok mért molalitása és a Van't Hoff egyenlet (NOBEL, 1991) alapján számítottuk ki, $20^{\circ} \mathrm{C}$-ra.

Prolintartalom meghatározása - A prolintartalom meghatározásához $50 \mathrm{mg}$ elporított levélmintát $1,5 \mathrm{ml} 3 \%$ szulfoszalicilsav-oldatban (J. T. Baker in: IBARRA-CABALLERO et al., 1987) homogenizáljuk, majd 12 órán át $4{ }^{\circ} \mathrm{C}$-on tartjuk. Ezt követöen az extraktumot centrifugálással $(9000 \mathrm{rpm}, 10$ perc) különválasztjuk a nem oldódó maradéktól. A prolintartalom meghatározása BATES és munkatársai (1973) alapján, $150 \mu 1$ extraktumból történt. Standardként Lprolin (Reanal, Budapest) 1 és 5 mmól.dm ${ }^{-3}$ koncentrációjú, $3 \%$ szulfoszalicilsav-oldatban elkészített oldatait használtuk, különböző hígításokban.

\section{Vizsgálati eredmények}

Prolintartalom összefüggése a sótartalommal természetes körülmények között élö Limonium gmelini egyedek levelében

A talaj vezetőképessége a $L$. gmelini vizsgált élőhelyén, a 15-20 cm-es mélységben 2,1 és $1,1 \mathrm{dS} \cdot \mathrm{m}^{-1}$ között változott (1:2,5 szuszpenzióban mérve) a vizsgált időszakban (1. táblázat). Ez az értéktartomány közelítőleg megfelel a

\section{1. táblázat}

Limonium gmelini subsp. hungarica levelének víztartalma (LVT) és élőhelyének talajvíztartalma (TVT), vezetőképessége (c), pH és pNa értékei 1:2,5 szuszpenzióban mérve, 1998. március 18. és október 10. között

\begin{tabular}{|c|c|c|c|c|c|c|}
\hline \multirow{2}{*}{ Időpont } & LVT & TVT & \multirow{2}{*}{$\begin{array}{c}E C \\
\left(d S \cdot m^{-1}\right)\end{array}$} & \multirow{2}{*}{ pH } & \multirow{2}{*}{ pNa } & \multirow{2}{*}{$\underset{\left(m m o ́ l . d m^{-3}\right)}{c}$} \\
\hline & \multicolumn{2}{|c|}{ (\% friss talaj) } & & & & \\
\hline márc. 18. & $71,4 \pm 4,8$ & 14,1 & 2,10 & 10,08 & 1,77 & 28 \\
\hline ápr. 1. & $75,5 \pm 3,0$ & 15,2 & 1,80 & 10,03 & 1,83 & 24 \\
\hline máj. 15. & $80,5 \pm 3,8$ & 10,0 & 1,36 & 9,50 & 2,00 & 18 \\
\hline júl. 24. & $76,7 \pm 1,0$ & 9,0 & 1,10 & 9,60 & 1,90 & 15 \\
\hline aug. 3 . & $74,6 \pm 3,3$ & 9,8 & 1,92 & 9,87 & 1,81 & 26 \\
\hline okt. 10. & $80,0 \pm 2,9$ & 18,0 & 1,16 & 9,42 & 1,85 & 16 \\
\hline
\end{tabular}

A talajoldat koncentrációjának (c) közelítő kiszámítása a telített talajoldat vezetőképessége alapján (in: TóTH, 1994) történt. A mintavétel helye: Kiskunsági Nemzeti Park, Fülöpszállás községtől 4 km-re, Limonio-Artemisietum santonici növénytársulásból 
15-28 mmól.dm ${ }^{-3}$ koncentrációjú NaCl-oldat vezetőképességének. A magas $\mathrm{pH}$ és $\mathrm{pNa}$ érték (1. táblázat) alapján a vízben oldható sók jelentős hányadát $\mathrm{Na}_{2} \mathrm{CO}_{3}$ és $\mathrm{NaHCO}_{3}$ alkotja. Mind a talaj vezetőképessége, mind a talaj $\mathrm{pH}$ és pNa értéke két csúcsot mutat a vizsgált időszakban, az elsőt márciusban, a másodikat augusztusban.

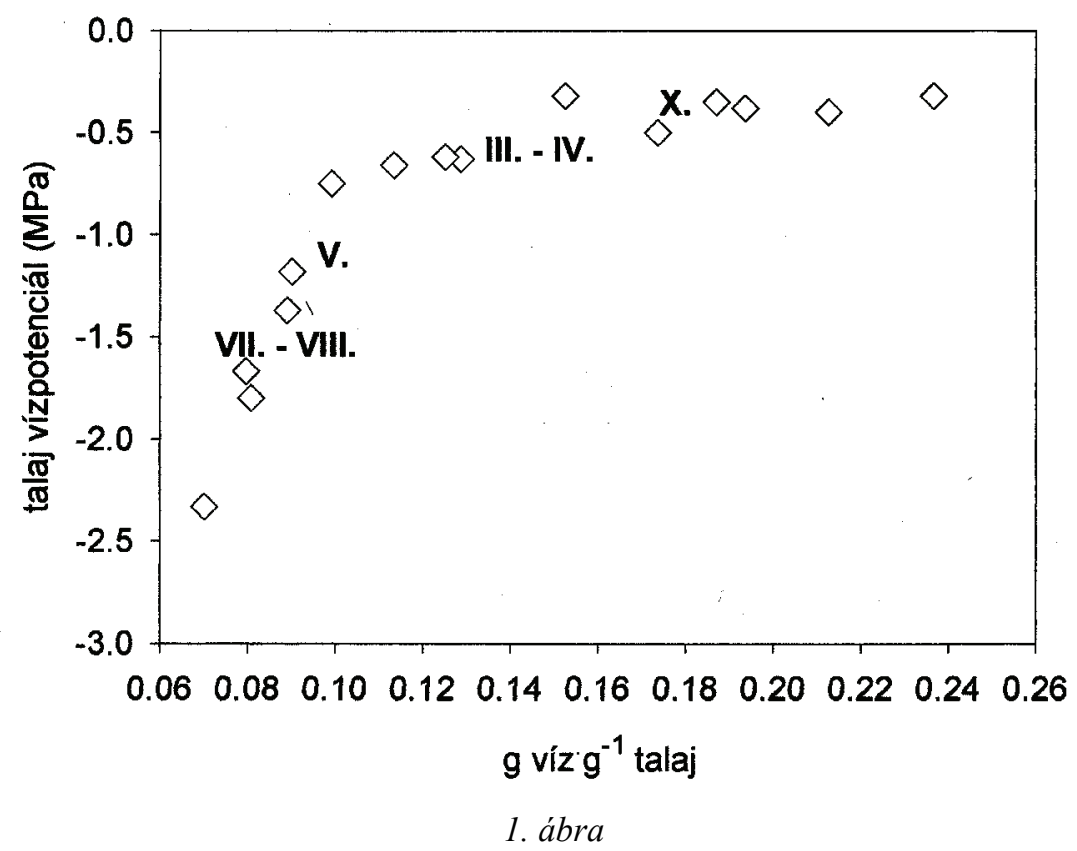

Szikes talaj víztartalom-nyomás görbéje, a Kiskunsági Nemzeti Park területén, Fülöpszállás község közelében található Limonio-Artemisietum santonici növénytársulásból, a felszíntől számított 15-20 cm mélységböl

A talaj nyomás-víztartalom görbéjének felvétele lehetővé teszi, hogy a talaj aktuális nedvességtartalmának ismeretében megadjuk a talaj vízpotenciálját. A vizsgált $L$. gmelini populáció élőhelyéröl, a felszíntől számított $15-20 \mathrm{~cm}$ mélységben a márciusi és augusztusi mintavételi idôpontokban a talaj számított vízpotenciál értéke -0,74 MPa, illetve -1,24 MPa volt (1. ábra).

Érdekes módon, a növények prolintartalma nem mutatott szoros összefüggést a környezet ozmotikus körülményeivel vagy sótartalmával (2. ábra). Ugyancsak nem tapasztaltunk prolinfelhalmozást levélvíztartalom-csökkenés

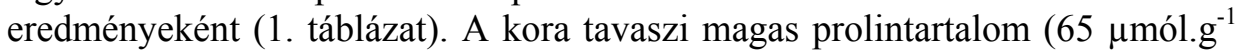
SZT) április elejére háromnegyedére csökkent, míg május közepén már csak 2,5 $\mu$ mól. $\mathrm{g}^{-1}$ SZT volt a levelek prolintartalma, amely érték nyár folyamán alig változott. Amennyiben a kora tavaszi erőteljes prolinakkumuláció a talaj magas 
(nátrium)-ion-tartalmával függ össze, úgy hasonló prolinfelhalmozást kellene tapasztalnunk július és augusztus hónapokban is, amikor a talaj pNa értéke szintén alacsony. Mivel ilyet nem tapasztaltunk, kontrollált körülmények között is megvizsgáltuk a nátriumionok hatását L. gmelini prolinakkumulációjára.

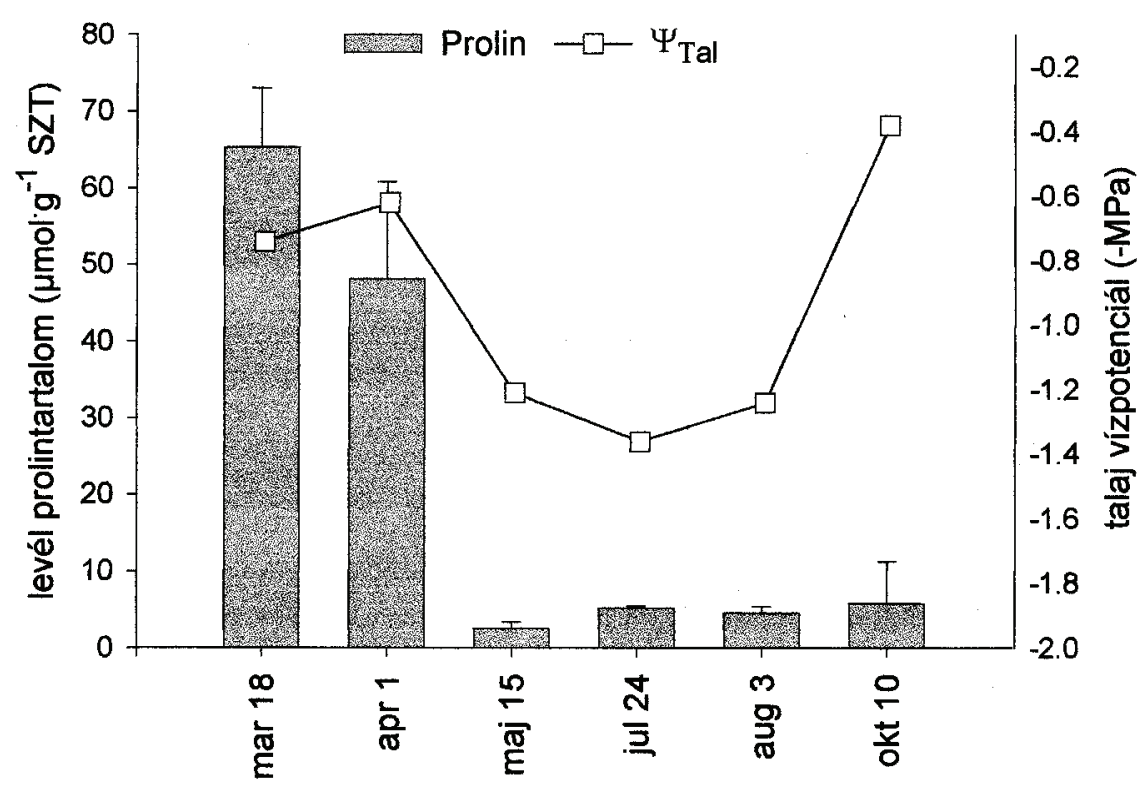

2. ábra

Limonium gmelini subsp. hungarica levelének prolintartalma és a talaj vízpotenciál értéke 1998. március 18 és október 10 között, 6 időpontban mérve. A mintavétel helye: lásd 1. táblázat

Prolintartalom kontrollált körülmények között nevelt Limonium gmelini egyedek levelében

A nátriumion prolintartalomra gyakorolt specifikus hatását kontrollált körülmények között, különböző NaCl-koncentrációk mellett vizsgáltuk, melyek ozmotikusan nem, vagy alig fejtettek ki hatást. Már $20 \mathrm{mmó} . \mathrm{dm}^{-3} \mathrm{NaCl}$ jelenlétében is prolinfelhalmozást tapasztaltunk, a kontrollhoz képest több mint négyszeresére nőtt a levelek prolintartalma (3. ábra). 100 mmól.dm ${ }^{-3} \mathrm{NaCl}$ hatására a prolin koncentrációja elérte a $70 \mu$ mól.g $^{-1}$ SZT mennyiséget, azaz a kontroll prolintartalmának 11-szeresét. A levelek mért ozmotikus potenciáljából ekkor a prolin részesedése $5 \%$ körüli volt. (A Cl-ionok jelenlétének specifikus szerepét nem vizsgáltuk.) 


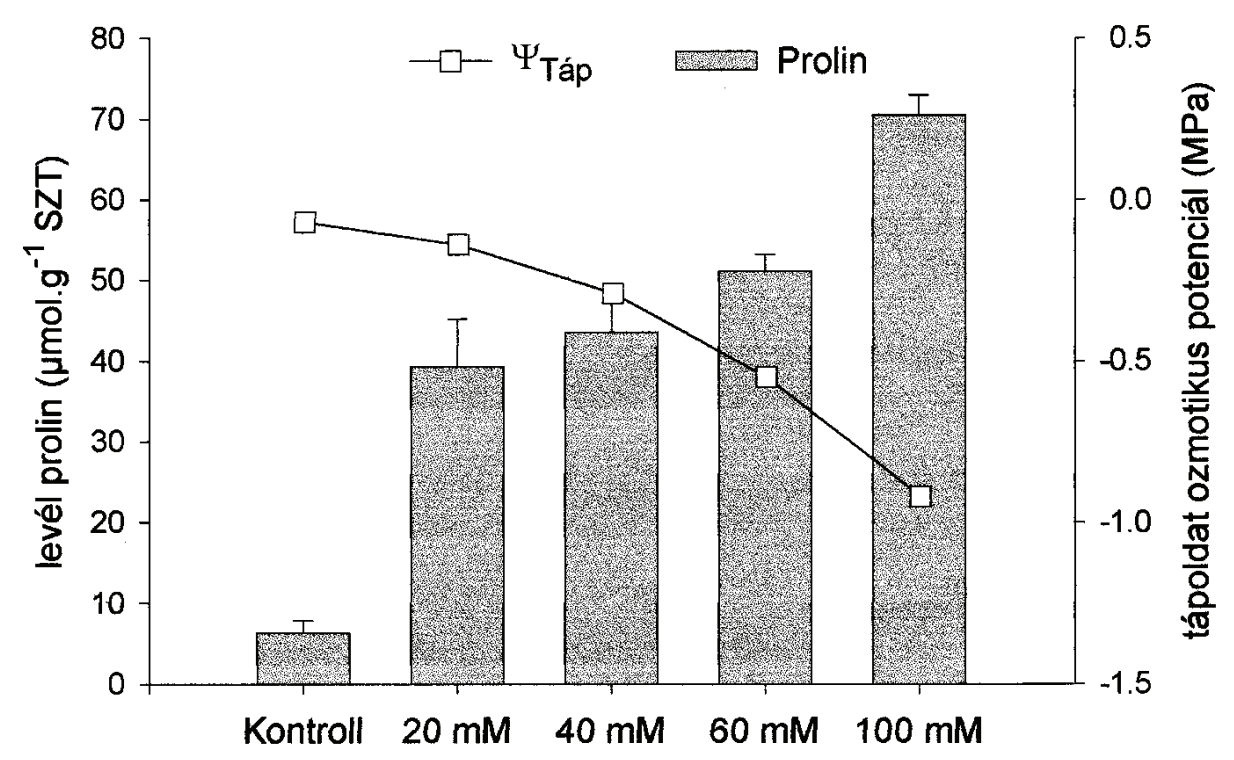

3. ábra

Limonium gmelini subsp. hungarica kontrollált körülmények között nevelt egyedek levelének prolintartalma és a tápoldat ozmotikus potenciálja. A növények csírakoruktól NaCl-kezelést kaptak, 0, 20, 40, 60 és $100 \mathrm{mM}$ koncentrációban a tápoldattal együtt.

Méréskor a növények 15 hetesek voltak

\section{Eredmények értékelése}

Számos mérés azt mutatja, hogy az ozmotikus stressz a levél meghatározott vízállapotának elérésekor vált ki prolin-akkumulációt. Lucernában ez a küszöbérték -2,1 MPa levél vízpotenciál (IRIGOYEN et al., 1992), míg kukoricában 83 \% levél víztartalom (IBARRA-CABALLERO, 1987). L. gmelini-ben sem természetes, sem kontrollált körülmények között nem figyeltük meg a prolin-akkumulációnak adott levél-vízállapot mellett bekövetkező kiváltódását, noha nem zárható ki, hogy nagyobb mértékủ ozmotikus stressz esetén ilyen válasz megnyilvánul.

Mivel mindkét esetben olyan növényeket vizsgáltunk, amelyek hosszú ideje voltak sós környezetnek kitéve, a prolin specifikus akkumulációja valószínüleg adaptív választ jelent. Ez az adaptív szerep valószínúleg nem az ozmotikus szabályozás, hiszen a prolin ozmotikus szerepe a NaCl-dal kezelt növényekben elhanyagolható volt (2. táblázat), és nem függött a levél víztartalom változásától (1. táblázat).

Szoros összefüggést mutat a léghömérséklet és a prolintartalom (MURAKEÖZY et al., 1999) L. gmelini-ben. Hideg által kiváltott prolinfelhalmozást 


\section{2. táblázat}

Limonium gmelini subsp. hungarica kontrollált körülmények között nevelt egyedek tápoldatának ozmotikus potenciálja $\left(\Psi_{\Pi \text { táp }}\right)$, valamint a növények leveleinek relatív és tényleges víztartalma, vízpotenciálja $\left(\Psi_{\text {lev }}\right)$ és ozmotikus potenciálja $\left(\Psi_{\Pi \text { lev }}\right)$

\begin{tabular}{|l|c|c|c|c|c|c|c|}
\hline \multirow{2}{*}{ Kezelés } & \multirow{2}{*}{$\Psi_{\Pi \text { táp }}$} & RVT & VT & $\Psi_{\text {lev }}$ & $\Psi_{\Pi}$ & $\Psi_{\text {Pro }}$ & $\begin{array}{c}\Psi_{\text {Pro }} / \\
\Psi_{\Pi} \\
\end{array}$ \\
\cline { 3 - 6 } & -MPa & \multicolumn{2}{|c|}{$\%$} & \multicolumn{3}{|c|}{-MPa } \\
\cline { 3 - 7 } Kontroll & 0,07 & $85,8 \pm 1,8$ & $78,3 \pm 0,9$ & $0,82 \pm 0,4$ & $2,1 \pm 0,1$ & $0,019 \pm 0,008$ & 0,9 \\
$20 \mathrm{mM}$ & 0,14 & $82,0 \pm 3,1$ & $80,7 \pm 0,6$ & $1,00 \pm 0,2$ & $2,8 \pm 0,1$ & $0,092 \pm 0,018$ & 3,3 \\
$40 \mathrm{mM}$ & 0,29 & $81,7 \pm 2,9$ & $78,4 \pm 0,4$ & $1,01 \pm 0,2$ & $2,1 \pm 0,2$ & $0,101 \pm 0,013$ & 4,8 \\
$60 \mathrm{mM}$ & 0,55 & $79,8 \pm 2$ & $77,5 \pm 0,6$ & $1,44 \pm 0,3$ & $2,9 \pm 0,2$ & $0,118 \pm 0,010$ & 4,1 \\
$100 \mathrm{mM}$ & 0,92 & $74,9 \pm 5,8$ & $72,9 \pm 1,5$ & $2,01 \pm 0,5$ & $2,9 \pm 0,2$ & $0,160 \pm 0,011$ & 5,5 \\
\hline
\end{tabular}

Megjegyzés: A levelek prolintartalmának számított ozmotikus potenciálja ( $\left.\Psi_{\text {Pro }}\right)$, valamint ennek részesedése az összes mért ozmotikus potenciálból ( $\left.\Psi_{\text {Pro }} / \Psi_{\Pi}\right)$ ugyancsak fel van tüntetve. A növények csírakoruktól NaCl-kezelést kaptak, 0, 20, 40, 60 és $100 \mathrm{mM}$ koncentrációban, a tápoldattal együtt. Méréskor a növények 15 hetesek voltak

mutattak ki számos más növényfajban (STEWART, 1981) is. XIN és BROWSE (1998), valamint IGARASHI és munkatársai (1997) szerint az alacsony hőmérséklet jelentősen fokozza a prolin bioszintéziséért felelős P5CS enzim expreszszióját, ami azt bizonyítja, hogy az alacsony hőmérséklet nem csupán fiziológiai szárazság előidézésén keresztül vált ki prolin-akkumulációt. Bizonyították azt is, hogy a prolin krioprotektív hatású a növényi sejtekben (WITHERS \& KING, 1979). Érdemes megfontolni azonban azt is, milyen metabolikus elönyökkel járhat a kora tavaszi prolin-akkumuláció a természetes körülmények között élő sóvirágban. A szikesek rossz vízgazdálkodási tulajdonságai következtében kora tavasszal a növények gyakran hipoxiás vagy anoxiás stressznek vannak kitéve. ZUDE-SASSE és LÜDDERS (2000) bizonyította, hogy anoxiás körülmények között mangó levelében és gyökerében is redukált koenzimek (NADH, NADPH) halmozódnak fel. HARE és munkatársai (1998) számos érvet sorakoztatnak fel amellett, hogy a prolin részt vesz a sejt redox-állapotának szabályozásában. A prolin termelése összességében NADPH-t fogyaszt (SAMARAS et al., 1995). Elképzelhető tehát, hogy a prolin szintézisén keresztül gondoskodik a növény az oxidált koenzimek megfelelő arányáról, melynek hiányában a fotoszintetikus rendszer oxidatív stresszt szenvedne. Ennek eldöntésére további vizsgálatok szükségesek. 


\section{Összefoglalás}

Noha számos adat gyült össze az elmúlt ötven évben a prolin specifikus akkumulációjával kapcsolatban, a prolin szerepe a magasabb rendủ növények sejtjeiben még ma sem világos.

A hazai szikesek pannóniai endemikus faja, a Limonium gmelini subsp. hungarica specifikus prolinfelhalmozását vizsgáltuk a sóstresszel összefüggésben, a márciustól októberig terjedő időszakban. Igen magas prolintartalmat (65 $\mu$ mól. $g^{-1}$ SZT) figyeltünk meg kora tavasszal, mely egybeesett a talaj vezetőképességének és Na-tartalmának első csúcsával. A márciusi magas prolintartalom a későbbiekben fokozatosan csökkent és alacsony értéken $\left(2,5-5 \mu \mathrm{mó} \mathrm{l.g}^{-1}\right.$ SZT) stabilizálódott. Nem következett be prolinfelhalmozás a nyár közepén, július és augusztus hónapokban, holott a talaj vízpotenciálja ekkor -1,5 MPa körüli értékre csökkent (a 15-20 cm-es talajmélységben), és a talaj sókoncentrációja a kora tavaszihoz hasonló értéket mutatott. Kontrollált körülmények között nevelt, hosszú távon (15 hét) sóhatásnak kitett L. gmelini növények igen

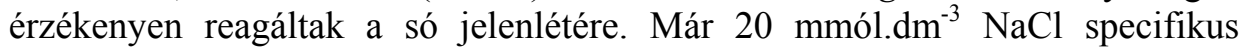
prolin-akkumulációt váltott ki a levelekben ( $39 \mu$ mól.g $\left.{ }^{-1} \mathrm{SZT}\right)$, és a sókoncentráció növelésével a prolinfelhalmozás fokozódott. A vizsgált koncentrációtartományban a $\mathrm{NaCl}$ ozmotikus hatása elhanyagolható vagy kicsi volt, a levelek víztartalmában nem mutatkozott lényeges csökkenés. A levelek ozmotikus potenciáljának kialakításában a prolin kb. 3-5 \%-kal részesedett a különböző sókezelésekben. Mindez azt támasztja alá, hogy a prolinfelhalmozás szerepe $L$. gmelini-ben elsősorban nem az ozmotikus szabályozás.

\section{Irodalom}

BATES, L. S. et al., 1973: Rapid determination of free proline for water-stress studies. Plant and Soil. 39. 205-207.

BOYER, J. S., 1982. Plant productivity and environment. Science. 218. 443-448.

DöRFLING, K. et al., 1993. In vitro-selection and regeneration of hydroxyprolineresistant lines of winter wheat with increasing proline content and increased frost tolerance. J. Plant Physiol. 142. 222-225.

Elthon, T. E. \& Stewart, C. R., 1981. Sub-mitochondrial location and electron transport characteristics of enzymes involved in proline oxidation. Plant Physiol. 67. 780-784.

FLOWERS, T. J., 1972: The effect of sodium chloride on enzyme activities from four halophyte species of Chenopodiaceae. Phytochemistry. 11. 1881-1886.

FLOWERS, T. J. et al., 1977. The mechanism of salt tolerance in halophytes. Annu Rev Plant Physiol. 28. 89-121.

GreEnWAY, H. \& MunNs, R., 1980. Mechanisms of salt tolerance in nonhalophytes. Ann. Rev. Plant Physiol. 31. 149-190. 
GreEnWAY, H. \& OSMOND, C. B., 1972. Salt responses of enzymes from species differing in salt tolerance. Plant Physiol. 49. 256-259.

HARE, P. D. et al., 1998. Dissecting the roles of osmolyte accumulation during stress. Plant, Cell and Environ. 21. 535-553.

HoAgland, D. R. \& ARNOLD, D. I., 1950. Water-culture methode for growing plants without soil. Calif. Agric. Exp. Stn. Circ., 374.

IBARRA-CABALLERO et al., 1987. Proline accumulation as a symptom of drought stress in maize: a tissue differentiation requirement. J. Exp. Bot. 39. 204. 889-897.

IGARASHI, Y. et al., 1997: Characterisation of the gene for $\Delta^{1}$-pyrroline-5-carboxylate synthetase and correlation between the expression of the gene and salt tolerance in Oryza sativa L. Plant Molec. Biol. 33. 857-865.

IRIGOYEN, J. J. et al., 1992. Water stress induced changes in concentrations of proline and total soluble sugars in nodulated alfalfa (Medicago sativa) plants. Physiol. Plant. 84. 55-60.

LARHER, F. et al., 1993. Effectors for the osmoinduced proline response in higher plants. Plant Physiol. and Biochem. 31. 911-922.

LEPORT, L., 1992. Accumulations de proline associees aux contraintes environmentales et a la floraison chez le colza (Brassica napus L.). Doktori értekezés. Université de Rennes I., U.F.R. Sciences de la Vie et de l'Environment.

Low, P. S., 1985. Molecular basis of the biological compatibility of nature's osmolytes. In: Transport Processes, Iono- and Osmoregulation (Ed.: GILLIES \& GILLIESBAILLIEN). 469-477. Springer-Verlag, Berlin.

LUTTS, L. et al., 1996. Effects of various salts and of mannitol on ion and proline accumulation in relation to osmotic adjustment in rice (Oryza sativa L.) callus culture. Plant Growth Regulation. 19. 207-218.

MARTINEZ, C. A. et al., 1996. In vitro salt tolerance and proline accumulation in Andean potato (Solanum spp.) differing in frost resistance. Plant Science. 116. 177-184.

MuRAKEÖZY, É. P. et al., 1999. Proline accumulation pattern in species of an inland saline habitat. Z. Naturforsch. 54c. 718-722.

Nobel, P. S., 1991. Physicochemical and Environmental Plant Physiology. 71--74. Academic Press, San Diego, California.

SAMARAS, Y. et al., 1995. Proline accumulation during drought and salinity. In: Environment and Plant Metabolism (Ed.: SMIRnOFF, N.). 161-187. BIOS, Oxford.

StewART, C. R., 1981. Proline accumulation: Biochemical aspects. In: Physiology and Biochemistry of Drought Resistance. 243-259. Academic Press, Australia.

SzABOLCS, I., 1981. Salt affected soils in the Hungarian Danube and Tisza Valleys. Agrokémia és Talajtan. 30. (Suppl.) 213-218.

SzABOLCS, I., 1994. Prospects of soil salinity for the $21^{\text {st }}$ century. Agrokémia és Talajtan. 43. 5-24.

TAYLOR, C. B., 1996. Proline and water deficit: ups, downs, ins, and outs. The Plant Cell. 8. 1221-1224.

TÓтн T., 1994. Talajtulajdonságok becslése a növényzet alapján tiszántúli szolonyec talajokon. Kandidátusi értekezés. MTA TAKI, Budapest.

XIN, Z. \& BROWSE, J., 1998. Eskimol mutants of Arabidopsis are constitutively freezing tolerant. Proc. Natl. Acad. Sci. USA. 95. 7799-7804. 
YANCEY, P. et al., 1982. Living with water stress: evolution of osmolyte systems. Science. 217. 1214-1222.

Withers, L. A. \& KING, P. J., 1979. Proline: a novel cryoprotectant for the freeze preservation of cultured cells of Zea mays. Plant Physiol. 64. 675-678.

WYN JONES, R. G. \& GORHAM, J., 1986. The potential for enhancing the salt tolerance of wheat and other important crop plants. Outlook Agriculture. 15. 33-39.

ZUDE-SASSE, M. \& LÜDDERS, P., 2000. Short- and long-term responses of mango trees to root zone anoxia. $12^{\text {th }}$ Congress of the Federation of European Societies of Plant Physiology, Budapest, 21-25 August, 2000. Plant Physiol. Biochem. 38. (Suppl.) 126.

Érkezett: 2001. március 5. 